\title{
TINJAUAN HUKUM ISLAM MENGENAI SISTEM PEMBAGIAN HASIL PENGELOLAAN KOPRA PUTIH DI DESA KATUMBANGAN
}

\author{
Muh. Anwar Hindi, Muhammad Nuzur, Fitriani Unalsi \\ Prodi Hukum Ekonomi Syariah, Fakultas Agama Islam, Universitas Al Asyariah Mandar \\ fitrianiunalsi48@gmail.com, anwarhindi@gmail.com.muh.nusur@yahoo.co.id
}

\begin{abstract}
This thesis is entitled An Overview of Islamic Law Regarding the Distribution System of White Copra Management Results in Katumbangan Village, Campalagian District, Polewali Mandar Regency. The purpose of this study is 1) To find out how the White Copra Management Results Sharing System in Katumbangan Village, Campalagian Subdistrict, Polewali Mandar District, 2) To find out How Islamic Law Review of White Copra Management Results Sharing System in Katumbangan Village, Campalagian District, Polewali Mandar District. This type of research uses qualitative methods, meaning that the type of research whose findings are not obtained through statistical procedures or other forms of calculation this research produces data in the form of words written or spoken from people and observed behavior, this research includes field research namely: collecting stiff data with research in place of the symptoms under study. The location of this research is located in Katumbangan Village, Campalagian District. Sources of data in this study are primary data sources and secondary data sources. Data collection methods consist of observation, in-depth interviews, documentation. Data processing and analysis techniques through 3 (three) stages, namely data reduction, data presentation, and drawing conclusions or verification. Testing the validity of the data using credibility criteria with inspection techniques in the form of triangulation. The results of this thesis study show that the distribution system of white copra management results in Katumbangan village, apparently uses 2 ways, namely being given wages after processing coconut into copra in terms of "anjoro mass" and given a coconut shell "directly ka'darona na ala" then a review of Islamic law regarding the white copra management profit sharing system, namely: profit sharing system in white copra business in Katumbangan Village that uses mudharabah agreement, which is the agreement or agreement between the capital owner and the white copra producer, in Islamic law everything is legal (allowed) allowed in Islam when it is for the common good does not harm one party or mensholimi. However, when the owner of the capital takes the proceeds of the sale of coconut shells that have become the rights and wages for the management of white copra to cover the losses incurred, then it hurts one party and is not in accordance with Islamic law.
\end{abstract}

Keywords: System for Sharing Copra White Management Results, Overview of Islamic Law regarding the Copra Management Results Sharing System.

\begin{abstract}
ABSTRAK
Penelitian ini berjudul Tinjauan Hukum Islam Mengenai Sistem Pembagian Hasil Pengelolaan Kopra putih Di desa Katumbangan, Kecamatan Campalagian, Kabupaten Polewali Mandar. Tujuan penelitian ini adalah 1) Untuk mengetahui Bagaimana Sistem Pembagian Hasil Pengelolaan Kopra Putih di Desa Katumbangan Kecamatan Campalagian Kabupaten Polewali Mandar, 2) Untuk mengetahui Bagaimana Tinjauan Hukum Islam Terhadap Sistem Pembagian Hasil Pengelolaan Kopra Putih di Desa Katumbangan Kecamatan Campalagian Kabupaten Polewali Mandar. Jenis penelitian ini menggunakan metode kualitatif, Artinya jenis penelitian yang temuannya tidak diperoleh melalui prosedur statistik atau bentuk hitungan lainnya penelitian ini menghasilkan data berupah kata-kata tertulis atau lisan dari orang dan perilaku yang diamati, penelitian ini termasuk penelitian lapangan yaitu: mengumpulkan data yang dikakukan dengan penelitian ditempat terjadinya gejala yang diteliti. Lokasi Penelitian ini bertempat di Desa Katumbangan Kecamatan Campalagian. Sumber data dalam penelitian ini yaitu sumber data primer dan sumber data sekunder. Metode Pengumpulan data terdiri dari obsevasi, wawancara mendalam, dokumentasi. Teknik pengolahan dan analisis data melalui 3 (tiga) tahapan yaitu reduksi data, penyajian data, dan penarikan kesimpulan atau verifikasi. Pengujian keabsahan data
\end{abstract}


menggunakan kriteria kredibilitas dengan teknik pemeriksaan berupa triangulasi. Hasil penelitian skripsi ini menunjukkan bahwa Sistem pembagian hasil pengelolaan kopra putih di Desa Katumbangan, ternyata menggunakan 2 cara yaitu diberi upah setelah mengolah kelapa menjadi kopra dalam hal "massisi anjoro" dan diberi tempurung kelapa "langsung ka'darona na ala" kemudian Tinjauan hukum islam mengenai sistem pembagian hasil pengelolaan kopra putih yaitu: sistem bagi hasil pada usaha kopra putih di Desa Katumbangan yang menggunakan akad mudharabah yaitu akad atau perjanjian yang disepati antara pemilik modal dan pengelolah kopra putih, di dalam hukum Islam segala sesuatunya itu Sah (boleh) diperbolehkan dalam Islam ketika sifatnya untuk kebaikan bersama tidak merugikan satu pihak atau mensholimi. Akan tetapi mana kala dari pihak pemilik modal mengambil hasil penjualan tempurung kelapa yang sudah menjadi hak dan upah bagi pengelola kopra putih untuk menutupi kerugian yang terjadi maka itu melukai satu pihak dan tidak sesuai dengan syariat Islam.

Kata Kunci: Sitem Bagi Hasil Pengelolaan Kopra Putih, Tinjauan Hukm Islam Mengenai Sistem Pembagian Hasil Pengelolaan Kopra putih.

\section{PENDAhuluAN}

\section{A. Latar Belakang}

Agama Islam mempunyai satu sumber pokok yang tetap yaitu Al-Qur'an. Diantara salah satu segi hukum yang terdapat di dalamnya adalah masalahmasalah Hukum Islam membenarkan seorang muslim berdagang atau usaha perseorangan, membenarkan juga menggabungkan modal dan tenaga dalam bentuk perkongsian (serikat dagang) kegotongroyongan yang memungkinkan usaha dapat berjalan dengan lancar. Namun Islam memberi ketentuan atauaturan usaha yang dilakukan baik secara perorangan maupun kelompok, yaitu dikategorikan halal dan mengandung kebaikan.

Salah satu contoh dalam usaha perkongsian yang banyak terjadi dalam masyarakat di Indonesia khususnya adalah kerja sama bagi hasil yang sifatnya saling menguntungkan kedua belah pihak, yaitu pemilik modal dan penerima modal. Pada masalah ini Islam memberi ketentuan hanya secara garis besar saja, yaitu apabila orang-orang melakukan kerjasama secara bersama-sama mereka akan menghadapi perbedaan dan perselisihan tentang masalah keuangan. Oleh karena itu sangat mutlak apabila perkara-perkara yang melibatkan uang atau benda yang bernilai dituliskan dalam bentuk kontrak atau perjanjian. ${ }^{1}$

Kopra adalah daging buah kelapa yang dikeringkan. Kopra merupakan produk kelapa yang sangat penting, karena kopra merupakan bahan baku pembuatan minyak kelapa. Untuk membuat kopra yang baik diperlukan kelapa yang telah berumur sekitar 60 hari dan memiliki berat sekitar 3 - 4 kg. Teknik pengolahan kopra ada empat macam, yaitu : Pengeringan dengan sinar matahari, Pengeringan dengan pengarangan atau pengasapan di atas api, Pengeringan dengan pemanasan tidak langsung, Pengeringan menggunakan solar system (tenaga panas matahari). Tetapi teknik yang digunakan masyarakat desa katumbangan dalam pengelolaan kopra putih adalah teknik pengeringan dengan sinar matahari. ${ }^{2}$

Berdasarkan latar belakang di atas maka ditentukan rumusan masalah adalah:

1. Bagaimana Sistem Pembagian Hasil Pengelolaan Kopra Putih di Desa Katumbangan?

2. Bagaimana Tinjauan Hukum Islam Terhadap Sistem Pembagian Hasil Pengelolaan Kopra Putih di Desa Katumbangan?

\footnotetext{
${ }^{1}$ Hendi Suhendi, Fiqh Muamalah, (Jakarta: Rajawali Pers, 2011). h.135

${ }^{2}$ http://foragri.blogsome.com, 15-11- 2011.Diakses pada kamis,2 Januari 2020. 10.36.wita
} 


\section{TINJAUAN PUSTAKA}

\section{A. Mudharabah}

Istilah mudharabah adalah bahasa yang digunakan oleh penduduk Irak, sedangkan penduduk Hijaz menyebut mudharabah dengan istilah mudharabah atau qiradh, sehingga dalam perkembangan lebih lanjut mudharabah dan qiradh juga mengacu pada makna yang sama. Secara lughowi mudharabah berasal dari kata ad-dharb (الضرب derivasi dari wazan fi'il ضربا - يضرب - ضرب (berti

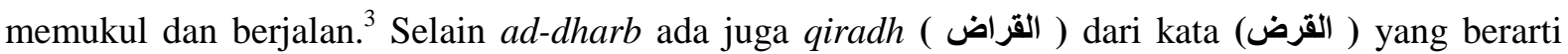
pinjaman atau pemberian modal untuk berdagang dengan memperoleh laba. ${ }^{4}$ Muhammad Syafi'I Antonio dalam bukunya Bank Syariah dari Teori Ke Praktek, menuliskan bahwa pengertian berjalan lebih tepatnya adalah proses seseorang dalam menjalankan usaha. ${ }^{5}$ Dari sini dapat dipahami bahwa mudharabah secara lughowi adalah proses seseorang menggerakkan kakinya dalam menjalankan usahanya dengan berdagang untuk memperoleh laba.

Secara istilahi mudharabah adalah menyerahkan modal kepada orang yang berniaga sehingga ia mendapatkan prosentase keuntungan. ${ }^{6}$ Definisi mudharabah menurut Sayyid Sabiq adalah :

"Akad antara dua pihak dimana salah satu pihak mengeluarkan sejumlah uang (sebagai modal) kepada lainnya untuk diperdagangkan. Laba dibagi sesuai dengan kesepakatan". ${ }^{7}$

Adapun definisi mudharabah menurut Wahbah Az-Zuhaili adalah : "Akad didalamnya pemilik modal memberikan modal (harta) pada 'amil (pengelola) untuk mengelolanya, dan keuntungannya menjadi milik bersama sesuai dengan apa yang mereka sepakati. Sedangkan, kerugiannya hanya menjadi tanggungan pemilik modal saja, 'amil tidak menanggung kerugian apa pun kecuali usaha dan kerjanya saja".

Sedangkan definisi mudharabah menurut fatwa DSN No. 07/DSNMUI/ IV/2000 adalah :

"Mudharabah adalah pembiayaan yang disalurkan oleh LKS kepada pihak lain untuk suatu usaha yang produktif. Dalam pembiayaan ini LKS sebagai shahibul maal (pemilik dana) membiayai 100\% kebutuhan suatu proyek (usaha), sedangkan pengusaha (nasabah) bertindak sebagai mudharib atau pengelola usaha". 9

Dari definisi diatas dapat ditarik kesimpulan bahwa pengertian mudharabah yaitu akad yang dilakukan oleh shahibul mal dengan mudharib untuk usaha tertentu dengan pembagian keuntungan sesuai kesepakatan. Keuntungan yang dituangkan dalam kontrak ditentukan dalam bentuk nisbah. Jika usaha yang dijalankan mengalami kerugian, maka kerugian itu ditanggung oleh shahibul mal

${ }^{3}$ Adib Bisri dan Munawwir, Al-Bisri Kamus Arab - Indonesia Indonesia -Arab, Surabaya : Pustaka Progressif, 1999, hlm. 432.

${ }^{4}$ Muhammad Syafi' I Antonio, Bank Syariah : Dari Teori Ke Praktek, Jakarta: Gema Insani h. 592.

5 Muhammad Syafi'I Antonio, Bank Syariah dari Teori ke Praktek, Jakarta: Gema Insani, 2001. h. 95.

${ }^{6}$ Abdullah Al-Muslih, Fikih Ekonomi Keuangan Islam, Jakarta : Darul Haq, 2004, h. 168.

${ }^{7}$ Sayyid Sabiq, Fiqhus Sunnah Jilid 4, Jakarta : Darul Fath, 2004, h. 217.

${ }^{8}$ Wahbah Az-Zuhaili, Fiqih Islam Wa Adillatuhu Jilid 5, Jakarta : Gema Insani, 2011, h. 476.

${ }^{9}$ Fatwa DSN Indonesia No. 07/DSN-MUI/IV/2000 tentang Pembiayaan Mudharabah

(Qiradh). 
sepanjang kerugian itu bukan akibat kelalaian mudharib. Namun jika kerugian itu diakibatkan karena kelalaian mudharib, maka mudharib harus bertanggung jawab atas kerugian tersebut.

\section{B. Kopra}

Kopra adalah daging buah kelapa yang sudah dikeringkan dengan pengasapan, panas matahari, atau dengan panas buatan. Kopra dipergunakan sebagai bahan baku pembuatan minyak kelapa dengan cara kering. Semakin baik cara pembuatan kopra, maka minyak yang dihasilkan akan semakin baik pula, kopra yang menghasilkan minyak yang jernih biasanya pembuatannya adalah dengan menggunakan cahaya matahari langsung karena kopra yang dihasilkan masih berwarna putih bersih, namun cara ini terkendala beberapa faktor yaitu ketidak efisienan lama waktu pengeringan yang dibutuhkan serta panas matahari yang kurang jika masuk musim penghujan, kopra yang dikeringkan dengan pengasapan biasanya menguning dan tidak bersih. Kelapa yang masih basah biasanya mengandung kurang lebih 50\% air dan 30\% minyak, namun setelah dijadikan kopra oleh petanipetani kelapa pada umumnya maka kadar air nya antara $15-22 \%$, setelah itu kopra yang sudah kering betul mengandung kurang lebih 2-3\% zat-zat mineral sehingga kopra yang sudah seperti ini layak untuk disimpan dalam suhu ruangan tertentu. Kadar air merupakan faktor utama untuk menentukan mutu kopra yang selanjutnya mempengaruhi jumlah minyak dan kualitas minyak yang dihasilkan. Kopra sendiri merupakan bahan yang mudah dirusak oleh berbagai organisme baik sewaktu masih dapat diproses pengolahan maupun dalam penyimpanan, kerusakan terutama terjadi bila kadar air dalam kopra melebihi kadar air semestinya. ${ }^{10}$ Kelapa kopra terbagi menjadi dua jenis yaitu:

\section{Kopra Putih}

Kopra putih adalah kelapa yang dikeringkan dengan menggunakan teknik sinar matahari secara langsung dan diberi obat sebagai pengawet kopra agar tidak berbulu. kopra putih juga tidak di potong-potong tetap utuh sesuai bentuknya seperti mangkok putih bersih kemudian di masukkan ke dalam karung ketika sudah dikeringkan kemudian di jual, dan nilai jual kopra putih lebih tinggi dari pada kopra hitam seperti pada gambar dibawah ini.

\section{Gambar 2.1Kopra Putih}

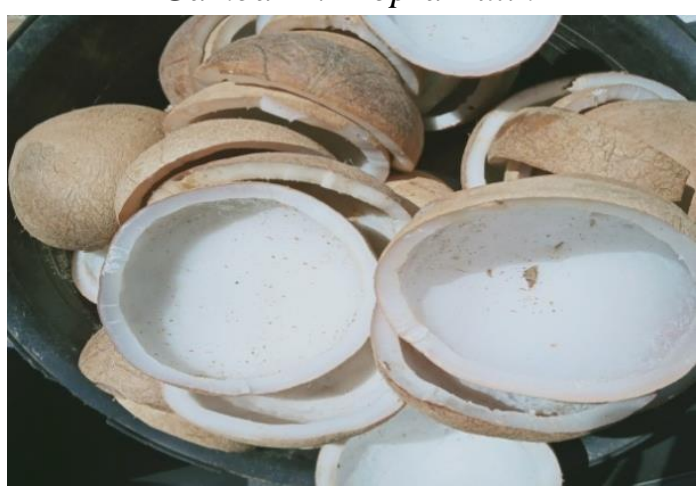

\section{Kopra Hitam}

Kopra hitam adalah kelapa yang dikeringkan dengan menggunakan teknik pengarangan atau pengasapan di atas api sampai betul-betul kering dan menghitam. Kopra jenis ini biasanya dipotongpotong kemudian dimasukkan kedalam karung kemudian di jual, nilai jual kopra hitam masih rendah dibandingkan dengan kopra putih, makanya masyarakat Desa Katumbangan lebih dominan mengola

\footnotetext{
${ }^{10}$ ISRA, Sistem Keuangan Islam : Prinsip dan Operasi, Jakarta : Rajawali Pers, 2015, h.359-360
} 
kopra putih dari pada kopra hitam karena lebih mudah,nilai jualnya mahal dan parktis cara pengolahannya. seperti pada gambar dibawah ini:

\section{Gambar 2.2Kopra Hitam}

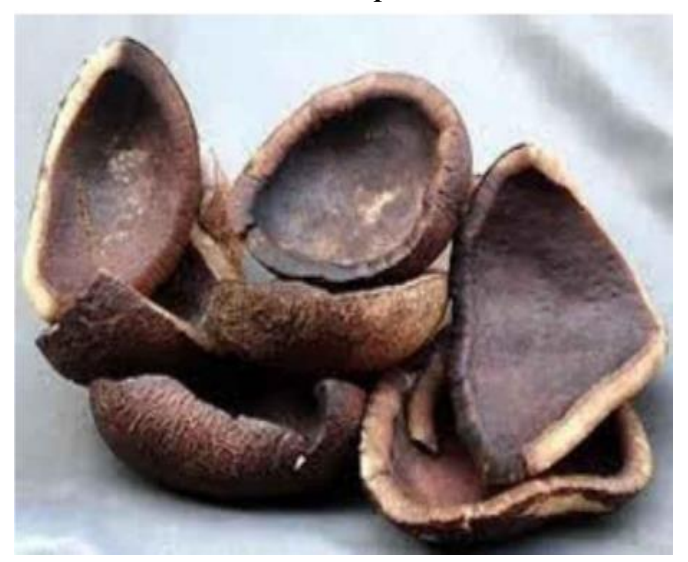

\section{METODE PENELITIAN}

\section{A. Jenis Penelitian}

Jenis penelitian ini menggunakan metode kualitatif, artinya jenis penelitian yang temuannya tidak diperoleh melalui prosedur statistik atau bentuk hitungan lainnya. Bodgan dan Taylor metode kualitatif adalah prosedur penelitian yang Menhasilkan data berupa kata-kata tertulis atau lisan dari orang dan prilaku yang diamati. Penelitian ini termasuk penelitian lapangan (field research) yaitu mengumpulkan data yang dilakukan dengan penelitian ditempat terjadinya gejala yang diteliti.

\section{B. Lokasi dan Waktu Penelitian}

Objek pada penelitian ini adalah para pengusaha pengelolaan kopra putih di Desa Katumbangan. Tempat penelitian di desa katumbangan kecamatan capampalagian, Adapun waktu penelitian yang ditempuh penulis adalah selama 2 (dua) bulan, dimulai sejak surat izin penelitian dikeluarkan.

\section{Sumber Data}

Data adalah sesuatu yang diperoleh melalui suatu metode pengumpulan data yang akan dianalisis dengan suatu metode tertentu yang selanjutnya akan menghasilkan suatu hal yang dapat menggambarkan atau mengidentifikasikan sesuatu. Dan adapun sumber data dalam penelitian ini dikelompokkan menjadi dua macam yaitu:

1. Data primer, yaitu data yang didapat dari sumber pertama di lapangan. Jenis data ini sering disebut dengan istilah data mentah yang berupa hasil angket dengan responden masyarakat.

2. Data sekunder, yaitu merupakan data yang berasal dari sumber kedua yang dapat diperoleh melalui buku-buku, brosur, dan artikel yang didapat dari wabsite yang berkaitan dengan penelitian ini. Untuk memperoleh data ini peneliti mengambil buku-buku, brosur wabsite dan contoh penelitian sebelumnya yang berkaitan dengan penelitian ini.

\section{Metode Pengumpulan Data}


Penyusunan dan pengumpulan data merupakan suatu yang penting. Oleh karena itu data harus dikumpulkan secara akurat, relevan, konprehensif bagi persoalan yang diteliti. Metode pengumpulan data dalam penelitian ini adalah sebagai berikut: ${ }^{11}$

1. Observasi

Observasi yaitu alat pengumpulan data yang dilakukan dengan cara mengamati dan mencatat sebagai sistematik gejala yang diselidiki. Metode ini dilakukan dengan cara mengamati secara langsung terhadap objek tertentu yang menjadi fokus penelitian dan mengetahui suasana pengolahan kelapa menjadi kopra putih serta sistem pembagian hasil yang digunakan di Desa Katumbangan, Kecamatan Campalagian dan mencatat sesuatu berhubungan dengan pelaksanaan pengolahan kopra putih serta pola bagi hasil yang digunakan.

2. Wawancara

Wawancara adalah proses tanya jawab dalam penelitian yang berlangsung secara lisan dalam satu, dua orang atau lebih dan mendengarkan secara langsung informasi dan keterangan. Metode pengumpulan data ini dilakukan dengan cara tanya jawab yang berkaitan dengan judul yang diangkat. Hal ini dilakukan agar tidak terjadi penyimpangan atau salah pengertian mengenai permasalahan yang diangkat. Wawancara dalam penelitian ini dilakukan dengan masyarakat di Desa Katumbangan, Kecamatan Campalagian, Kabupaten polewali mandar

\section{Dokumentasi}

Dalam penelitian ini menggunakan dokumentasi yang langsung diambil dari objek penelitian di Desa Katumbangan, Kecamatan Campalagian Kabupaten Polewali Mandar, yaitu berupa foto-foto bersama dan kegiatan masyarakat dalam mengola kelapa menjadi kopra putih.

\section{E. Tekhnik Pengolahan dan Analisa Data}

Melalui tekhnik pengolahan data maka data mentah yang telah dikumpulkan peneliti menjadi berguna. Analisis data sangat penting dalam mengelola data yang sudah terkumpul untuk diperoleh arti dan makna yang berguna dalam pemecahan masalah. Analisis data dalam penelitian ini adalah analisis data kualitatif, proses analisis data secara kualitatif dimulai dengan menelaah data yang diperoleh dari berbagai sumber atau informasi, baik melalui wawancara maupun dokumentasi.

Data tersebut terlebih dahulu dibaca setelah dipelajari kemudian dianalisis. Untuk meminimalisir kesalahan yang mungkin terjadi yang berkaitan dengan pengambilan sampel dan tekhnik wawancara maka digunakan triangulasi, tekhnik ini bertujuan untuk melakukan pengecekan ulang dengan cara menggabungkan berbagai jenis metode kualitatif sehingga data yang diperoleh akan lebih tuntas dan pasti. Berikut ini tekhnik analisis data yang digunakan oleh peneliti:

1. Reduksi data

Reduksi data adalah merupakan bagian dari analisis. Reduksi data merupakan suatu bentuk analisis yang menajamkan, menggolongkan, mengarahkan, membuang yang tidak perlu dan mengorganisasi data dengan cara sedemikian rupa hingga kesimpulannya dapat ditarik.

\section{Triangulasi}

Tringulasi digunakan sebagai tekhnik untuk mengecek keabsahan data dimana pengertian triangulasi adalah tekhnik pemeriksaan keabsahan data yang memanfaatkan sesuatu yang lain dengan membandingkan hasil wawancara dan hasil penelitian. ${ }^{12}$

\footnotetext{
${ }^{11}$ Sugiyono, Metode Penelitian Kombinasi Kualitatif dan Kuantitatif (Bandung).Diakses pada 4 Januari 2020.10:10 Wita.

12 Halim Malik, Https//www.kompasiana.com/unik penelitian kualitatif. 30 agustus 2018
} 
Dari kedua tekhnik diatas, penulis juga menggunakan proses yaitu dengan mencatat hal-hal yang berkaitan dengan catatan lapangan serta menganalisis data dengan menggali hubungan dan pola antar data.

\section{HASIL PENELITIAN}

\section{A. Sistem Pembagian Hasil Pengelolaan Kopra Putih di Desa Katumbangan.}

Berdasarkan observasi yang dilakukan oleh penulis diketahui bahwa masyarakat Desa Katumbangan dalam mengolah kelapa menjadi kopra dimulai pertama kali berjalan di tahun 2010 . Pada awalnya kopra hitam yang pertama kali di olah oleh masyarakat Desa Katumbangan, tetapi seiring berjalannya waktu nilai jual kopra hitam dengan tekhnik pengasapan menurun dari kopra putih. Masyarakat Desa Katumbangan mulai beralih ke kopra putih. Teknik pengolahan Kopra Putih pun efisien dan mudah dikerjakan, ibu-ibu bisa ikut serta dalam mengolah kelapa menjadi kopra putih. Kopra putih ditaksir dalam $1 \mathrm{~kg}$ Rp. 9.200 nilai jualnya. Dalam 1 karung bisa mencapai $65 \mathrm{~kg}$ jadi harga kopra per karungnya mencapai Rp. 598.000. Maka masyarakat Desa Katumbangan beralih ke kopra putih sebagai kegiatan usaha dan menambah pendapatan untuk memenuhi kebutuhan hidup.

Kegiatan usaha kopra ini dilakukan hampir seluruh masyarakat Desa Katumbangan, di samping kegiatan membajak sawah dan menanam padi belum di lakukan, maka usaha kopra putih inilah yang menjadi kegiatan pengganti untuk memenuhi kebutuhan hidup keluarga. Adapun akad atau perjanjian yang disepakati antara pemilik modal dengan pengelola dilakukan secara hukum adat yaitu: perjanjian kerja sama pemilik modal dengan pengelola kelapa hingga menjadi kopra dilakukan secara lisan tampa adanya perjanjian tertulis antara pemilik kelapa dengan pengelolah.

Wawancara pertama yang dilakukan oleh penulis dengan masyarakat Desa Katumbangan pemilik kelapa mengenai sistem pembagian hasil pengelolaan kopra putih. Berdasarkan hasil wawancara dengan pemilik modal pengelolaan kelapa yaitu bapak Syamsuddin mengenai cara pembagian gaji karyawan pengelolaan kopra putih mengatakan bahwa:

"Mua masalah upah atau gaji tergantung sangapa i na ulle na sisi anjoro, mua 1000 anjoro na sisi 160 rb gajinna. Dian tomandi tappa ka'darona na ala, na tunui menjadi arang mane na baluan. Tergantung kesepakatan di awal.",13

Terjemahannya:Untuk masalah upah atau gaji dilihat dari berapa banyak buah kelapa yang mampu dipisahkan dengan tempurungnya. Jika karyawan atau pengelola kopra putih mampu memisahkan buah kelapa denga tempurungnya sebanyak 1000 buah kelapa maka diberi upah sebanyak 160 ribu rupiah. Ada juga karyawan yang memilih mengambil tempurung kelapa sebagai upah, di bakar menjadi arang kemudian di jual.Berdasarkan akad di awal antara pemilik modal dan pengelola.

Setelah penulis mewawancarai bapak syamsuddin mengenai sistem pembagian hasil pengelolaan kopra putih, penulis kembali bertanya, berapa jumlah karyawan yang bapak pekerjakan untuk mengolah kopra putih di Desa Katumbangan dan berapa kali karyawan bapak syamsuddin menerima upah atau gaji dalam sebulannya. Hal ini sesuai yang disampaikan oleh bapak Syamsuddin sebagai berikut:

${ }^{13}$ Wawancara dengan bapak Syamsuddin, pemilik kelapa Dusun Katumbangan, Campalagian 2 maret 
"Mai'diih diang 10 sola dan biasai pi appe na tarima sambulan, mua pura bomi massisi anjoro di gaji boi. Bedai mua ka'darona na ala biasa tia si sambulan mane na ala ka'darona na apa napasirumunggi dolo mane na tunu. Iyau ma tanggung obat,karung,anjoro. Sangga na jama mi tia karyawannu."

Terjenahannya: Banyak, sekitar 10 orang dan terkadang 4 kali menerima gaji dalam sebulannya, ketika karyawan sudah bekerja memisahkan buah kelapa dengan tempurungnya maka diberu upah. Berbeda dengan sistem penerimaan upah atau gaji yang mengambil langsung dari tempurung kelapa karena harus dikumpul dulu sehingga menjadi banyak dan di bakar menjadi arang. Saya yang bertanggung jawab mengenai alat dan bahan yang digunakan mengolah kelapa menjadi kopra seperti: obat, karung, buah kelapa dan lain-lain, karywan atau pengelola hanya bekerja menggunakan tenaga saja.

Berdasarkan wawancara penulis dengan salah satu warga masyarakat pemilik kelapa (pemilik modal) ternyata sistem pembagian hasil dalam pengelolahan kopra putih menggunakan 2 sistem yaitu:

1. Diberi upah setelah berhasil memisahkan kelapa dengan tempurungnya mencapai 1000 biji di "sisi" senilai 160 ribu rupiah.

2. Diberi tempurung kelapa setelah mengolah kelapa menjadi kopra putih. "ka'darona na ala". Sistem pembagian hasil yang kedua ini diperlakukan bagi karyawan perempuan ibu-ibu maupun anak-anak, yang pekerjaanya khusus menjemur dan sebagainya hingga kopra siap di jual. pada sistem yang kedua inilah biasanya karyawan tidak digaji karena hasil penjualan tempurung kelapa yang biasaya menjadi upah pekerja harus ditahan untuk menutupi kerugian yang terjadi, tidak semua hasil penjualan kopra ini di ambil oleh pemilik modal akan tetapi hanya sebagian dari hasil penjualan kopra.

Kedua sistem diatas sudah disepakati oleh masyarakat Desa Katumbangan khususnya bagi pemodal dan pengelola kopra putih. Walaupun salah satu dari sistem pembagian upah di atas merugian sebagian karyawan para pekerja pengelolaan kopra putih akan tetapi pekerjaan ini tetap dilakukan untuk memenuhi kebutuhan hidup selain kegiatan membajak sawah hingga panen padi belum dilakukan maka pengelolaan kopra menjadi pekerjaan pengganti bagi para masyarakat khususnya bagi pengelola kopra putih. Bapak syamsuddin memiliki sekitar 10 karyawan laki-laki maupun perempuan yang ia pekerjakan dalam mengelola kopra putih dalam pengelolahannya pemilik modal bertanggung jawab penuh mengenai alat dan bahan yang digunakan dalam pengolahan kelapa hingga menjadi kopra putih dan siap di jual.

Kemudian penulis mempertanyakan tentang sistem bagi hasil yang menggunakan 2 cara tersebut dalam pembagian hasil untuk pemberian upah ini. Berdasarkan hasil wawancara dengan pemilik usaha kopra tidak ada karyawan yang komplen atau dirugikan dalam bekerja, malahan karyawan biasa dibantu dalam hal gaji karena mereka diperbolehkan mengambil upah terlebih dahulu sebelum bekerja. Hal ini sesuai dengan hasil wawancara sebagai berikut:

"Alhamdulilah selama die mai ma usaha boka puteh i tau ehh na diang mo la'bi sappulo taunna e andiang to tuuh diang kompleng, cuman terkadang mua meloi di gaji yahhh dibengan bomi istilahnah mappanjar $i$."

Terjemahannya: Alhamdulillah selama hampir kurang lebih 10 tahun belum pernah ada karyawan atau pengelola yang komplen mengenai persoalan gaji. Cuman terkadang ketika karyawan membutuhkan uang untuk kebutuhan keluarga maka upah yang diterima di minggu depan bisa di ambil hari ini juga. 
Berdasarkan hasil wawancara diatas penulis dapat menganalisis bahwa masyarakat yang mengelola kopra putih tidak pernah mengeluh kepada pemilik modal mengenai persoalan gaji atau upah yang diterimah walaupun terkadang para karyawan merasa ada yang mengganjal di hati akan tetapi tidak pernah disampaikan langsung kepada pemilik modal. Dalam bahasa mandar dan bahasa sehari-hari masyarakat desa katumbangan. "indani lawe-lawean". Justru pemilik modal memberikan kemudahan kepada pengelola mengenai gaji, bisa diterimah terlebih dahulu sebelum bekerja.

Dalam pengelolaaan kopra putih di Desa Katumbangan beberapa kali terjadi kerugian dan yang menanggungnya adalah pemilik usaha kopra putih. Dari kerugian itu biasanya karyawan tidak digaji terlebih dahulu karena dipakai untuk menutupi kerugian tersebut. Hal ini sesuai dengan hasil wawancara penulis sebagai berikut:

"iyya ruai beberapa kali, cuman ndak sering-sering ji. Mua tiba -tiba boi tau rugi die ma kopra putih eh yang tanggung adalah pemilik modal atau pemilik kelapa, tapi pada saat itu gaji karyawan di tahan untuk menutupi kerugian yang terjadi."

Terjemahannya: Ia pernah terjadi kerugian beberapa kali, hanya saja tidak setiap hari. Terkadang ketika terjadi kerugian dalam mengolah kelapa menjadi kopra putih yang bertanggung jawab menanggung kerugian itu adalah pemilik modal, tetapi pada saat itu gaji atau upah karyawan di ambil untuk menutupi kerugian yang terjadi.

Dari hasil wawancara di atas penulis dapat menganalisis bahwa dalam pengelolahan kelapa menjadi kopra putih yang siap dijual biasa terjadi sedikit masalah yaitu kerugian dalam pengelolahannya. Kerugian bisa terjadi tampa diketahui sebelumnya baik pengelolah maupun pemilik modal, untuk menutupi kerugian yang terjadi

Adapun masalah konfirmasi tentang penahanan gaji oleh karyawan terkadang ada pemberitahuan sebelumnya dan biasa juga tidak ada. Hal ini terungkap dari hasil wawancara sebagai berikut:

"biasai na issang, biasa tomandi tappa mengerti tappa mi lao mua tiba-tiba boi rugi tau maboka, apa iyya dio alli ka'darona o dipake menutupi kerugian",14

Terjemahannya: Terkadang ada pemberitahuan sebelumya dan biasa juga tidak ada, biasanya karyawan atau pengelola hanya pasrah ketika terjadi lagi kerugian. Hasil penjualan tempurung kelapa menjadi asasaran untuk menutupi kerugian.

Dari hasil wawancara di atas penulis dapat menganalisis bahwa dalam sistem pembagian hasil yang diterapkan masyarakat di Desa Katumbangan dalam mengolah kelapa menjadi kopra putih menggunakan dua cara yaitu diberi upah senilai 160 ribu rupiah setelah mencapai 1000 biji di "sisi". Dan diberi tempurung kelapa setelah mengolah kelapa menjadi kopra putih. "ka'darona na ala". Dari kedua sistem pembagian hasil yang sudah disepakati antara pemilik modal dan pengeloah di atas Alhamdulillah kedua sistem yang digunakan masyarakat Desa Katumbangan untuk pembagian hasil dalam pemgelolaan kelapa hingga menjadi kopra sudah disepakati dan diterima baik oleh masyarakat, walaupun terkadang terjadi kerugian atau keterlambatan gaji (upah) yang diberikan akibat beberapa faktor yaitu: kerugian dalam pengelolahan kelapa menjadi kopra putih.

\footnotetext{
${ }^{14}$ Wawanc ara dengan bapak Syamsuddin, pemilik kelapa Dusun Katumbangan, Campalagian 2 maret 2020
} 
Wawancara kedua yang dilakukan penulis dengan masyarakat Desa Katumbangan dengan karyawan pengelola kopra putih mengenai sistem bagi hasil yang diperlakukan dan telah disepakati. Berikut adalah hasil wawancara dengan ibu Fadilah mengenai lamanya menjadi karyawan serta sistem pembagian upah yang di terima dalam pengelolaan kopra putih ialah:

"Baru ji, apa indang tomandi ma kopra lomeang di jama biasa i tau ma boka si 6 bulan miosa boi tau apa tibolo lau i tau di galung ma tanam padi, anna massangking. Tapi mиa nandiang bomo di jama yahhh ma boka boi tau, di sio i bos mi bawangan kelapa mane di kopra putih i. Kira-kira sekitar 3 tahun lah. Mua gaji mibenganni bos diang ma ala ka'darona dian tomandi tappa na gaji 160 rb mua pura bomi massisi anjoro 1000 mua bassa die ita tobainee kadarona di ala, apa ma alloi tappai tau, anna mandurui, mиa tommoanena massisi $i$, na gaji 160 rb nua diang mo 1000 na sisi."

Terjemahannya: Saya baru-baru ini mulai bekerja mengolah kelapa menjadi kopra karena terkadang saya bekerja, sekitar 6 bulan saya berhenti lagi beralih ke sawah menanam padi dan panen padi. Tetapi ketika tidak ada kerjaan lain lagi maka saya kembali mengolah kelapa menjadi kopra putih saya meminta kepada pemilik modal untuk memberikan saya pekerjaan. Saya sudah hampir 3 tahun mengolah kelapa menjadi kopra putih. Untuk persoalan gaji yang pemilik modal berikan kepada saya, ada yang tempurung kelapanya di ambil dan ada juga diberi upah 160 ribu rupiah ketika telah memisahkan kelapa dengan tempurungnya sebanyak 1000 biji. Kalau karyawan perempuan biasanya tempurung kelapa yang di ambil karena tugas saya hanya menjemur dan menyimpan berbeda dengan laki-laki yang di beri upah berupa uang 160 ribu rupiah ketika mencapai 1000 biji di pisahkan dengan tempurungnya.

Para karyawan mulai bekerja mengolah kelapa menjadi kopra putih, salah satu kegiatanya yaitu mengeringkan kopra putih di mulai dari jam 6 pagi dan mengangkatnya dilakukan pada sore hari, kemudian dilanjut jam 7 sampai jam 12 malam memisahkan kelapa dengan tempurungnya. Hal ini sesuai dengan yang dikatakan oleh ibu Nurbaya yang mengatakan bahwa:

"Pagi, sekitar jam 6 apa mua marrang i allo indani di ulle maalloi. Dialloi i malimang mane didurui sore, biasa tomandi di jagai mua indani di obat apa na tittoi manu anjoro(kelapa), mua di obai i indani na tittoi manu. Mane dilanjut bomi bongi jam 7 sampai jam 10 bahkan sampai jam 12 malam mua maidi boi anjoro na sisi tommoane na, tobainne na mandurui ka'darona anu pura na sisi."

Terjemahannya:Pagi,sekitar jam 6 karena ketika matahari sudah mulai panas kami tidak sanggup berada terlalu lama dibawah sinar matahari. Dijemur di pagi hari dan di angkat di sore hari, terkadang di awasi ketika kelapa tidak diberi obat ketika dijemur karena digigit ayam buah kelapanya. Kemudian di lanjut dimalam hari pada jam 7 sampai jam 10 dan bahkan sampai jam 12 malam ketika banyak buah kelapa yang harus dipisahkan dengan tempurungnya biasanya laki-laki yang memisahkan kelapa denga tempurungnya, perempuan yang memunguti tempurunnya dan di simpan.

Selama mengelola kelapa menjadi kopra putih, gaji karyawan biasa mengalami kendala, seperti yang dikatakan Ibu Nurbaya kepada penulis sebagai berikut: 
"Kadang-kadang i macet gaji, tapi simata di pera u i lao bos mua pura bomi tau massisi atau masaemi di sa'ding indang rua migaji, 15

Terjemahannya:Terkadang mengalami kemacetan dalam pemberian gaji, akan tetapi kami selalu minta kepada bos ketika sudah memisahkan kelapa dengan tempurungnya dan menjemur kelapa hingga kering atau dirasakan sudah terlalu lama belum menerima gaji.

Dari wawancara di atas antara penulis dan beberapa tokoh masyarakat para pekerja pengelolaan kopra putih maka penulis dapat menganalisis bahwa para karyawan bekerja mulai pagi sampai malam hari sesuai dengan keadaan yang ada. ketika kelapa yang ingin di kopra banyak maka sampai malam hari. Ketika gaji untuk karyawan mengalami kemacetan maka karywan biasa meminta atau mengkonfirmasi langsung ke pemilik modal.

\section{Tinjauan Hukum Islam Terhadap Sistem Pembagian Hasil Pengelolaan Kopra Putih di Desa Katumbangan.}

Banyak ayat al-Quran dan hadis Nabi Saw. yang memerintahkan manusia agar bekerja. Manusia dapat bekerja apa saja menurut kemampuan yang dimilikinya yang ter penting tidak melanggar garis-garis yang telah ditentukannya. Manusia bisa melakukan aktifitas produksi, seperti pertanian, perkebunan, peternakan, pengolahan makan dan minuman. Manusia juga dapat melakukan aktifitas distribusi, seperti perdagangan atau dalam bidang jasa, seperti transportasi, kesehatan, dan sebagainya. Akad mudarabah dibolehkan dalam Islam, karena bertujuan untuk saling membantu antara pemilik modal dengan pakar atau ahli dalam memutar modal dan sama-sama mencari keuntungan. Banyak diantara pemilik modal yang tidak mampu dalam mengelola dan memproduktifkan uangnya, sementara banyak pula yang memiliki kemampuan dibidang perdagangan namun tidak memiliki modal untuk berdagang. Atas dasar saling menolong dalam pengelolaan modal itu, Islam memberikan kesempatan untuk saling bekerjasama antara pemilik modal dengan seseorang yang terampil dalam mengelola dan memproduktifkan modal tersebut, Sebagaimana yang difirmankan Allah Swt dalam al-Qur'an Surat An-nisa ayat 29:

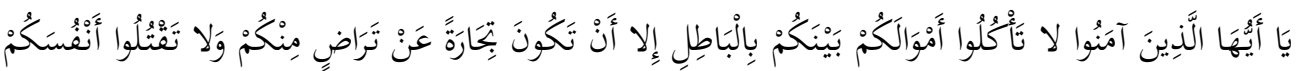

$$
\begin{aligned}
& \text { إِنَّ اللَّه كَانَ بِكُمْ رَحِيمًا }
\end{aligned}
$$

Terjemahnya: Hai orang-orang yang beriman, janganlah kamu saling memakan harta sesamamu dengan jalan yang batil, kecuali dengan jalan perniagaan yang Berlaku dengan suka sama-suka di antara kamu. dan janganlah kamu membunuh dirimu; Sesungguhnya Allah adalah Maha Penyayang kepadamu.

Imam Al-Marwadi berdalil tentang keabsahan Mudharabah dengan firman Allah Swt surah al-Baqarah ayat 198:

\footnotetext{
${ }^{15}$ Wawancara dengan ibu Nur baya, pengelolakopra putih Dusun Katumbangan, Campalagian 3 Maret
} 


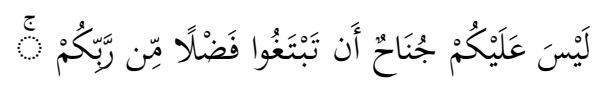

Terjemahnya : Tidak ada dosa bagimu untuk mencari karunia (rezki hasil perniagaan) dari Tuhanmu

Penulis mewawancarai salah satu tokoh masyarakat Desa Katumbangan Imam Mesjid "Jami Al-Iittihad" dusun Katumbangan Bapak Syamsuddin mengenai tinjauan hukum Islam terhadap sistem pembagian hasil pengelolaan kopra putih yang diterapkan di Desa Katumbangan. Berikut penjelasan beliau Bapak Syamsuddin kepada penulis.

"Pengelola kopra putih dini di desa katumbangan hampir semua masyarakatnya mengelola atau maboka puteh sebagai kegiatan usaha menambah perekonomian keluarga dalam memenuhi kebutuhan hidup kelurganya. Antara pengelola kopra putih dengan pemilik kelapa saling bekerja sama mengolah kopra putih dengan menggunakan sistem bagi hasil atau upah yang sudah sesuai dengan ajaran Islam. Disamping itu antara pengelola kopra putih dengan pemilik kelapa menjaling kerja sama untung rugi di bagi rata, sesuai kesepakatan di awal. Alhamdulillah selama kegiatan usaha kopra putih di Desa Katumbangan ini mampu meningkatkan lapangan pekerjaan bagi masyarakat khususnya Desa Katumbangan dalam memenuhi kebutuhan sehari-hari,dan kebutuhan lainnya.Sistem bagi hasil yang digunakan dan disepakati antara pemilik modal dan pengelola kopra putih dalam mengelola kelapa menjadi kopra putih. menurut saya pribadi sebagai Imam Masjid Jami Al-Ittihad dan mewakili pendapat dan keadaan masyarakat Desa Katumbangan sudah sesuai dengan yang telah di ajarkan dalam agama dan kepercayaan kita. Sebagaimana juga di jelaskan di dalam al-Qur'an sebagai pedoman hidup manusia yang bisa di contoh dan diterapkan dalam kehidupan sehari- hari sebagai manusia,selama dalam kegiatan usaha pengelolaan kopra putih ini antara pengelola saling terbuka mengenai untung dan ruginya kegiatan usaha pengelolaan kopra putih ini maka akan selalu baik-baik saja intinya kembali ke Ijab dan Qabunya",16

Setelah penulis mewawancarai tokoh masyarakat Imam Mesjid Jami' Al- Ittihad Desa Katumbangan, penulis tidak langsung mengambil kesimpulan penulis mewawancarai dan meminta pendapat salah satu tokoh masyarakat ibu ustazah Nur Hidayah selaku guru ngaji anak- anak di Desa Katumbangan sekaligus memiliki sendiri TPA (tempat pengajian anak-anak) di depan rumahnya. Ia sangat terkenal dengan bacaan al-gur'annya yang sangat indah dan sudak keliling kota. ustazah Nur Hidayah adalah salah satu tokoh masyarakat yang sangat terkenal di desa katumbangan. Berikut hasil wawancara penulis dengan ustazah Nur Hidayah.

"Menurut pendapat saya sebagai anak yang mewakili ustazah Nur Hidayah karena sementara beliau tidak bisa digangu karena sedang istirahat. Dalam kegiatan usaha harus adil seimbang dan sama rata sesuai kesepakatan di awal, kita sebagai pemilik modal yang memberikan pekerjaan kepada para pengelolah yang ingin bekerja untuk memenuhi kebutuhan kelurga mereka asalkan tidak terlalu memeras tenaga sesuai dengan pekerjaan dan upah yang diterimah boleh-boleh saja kalaupun misalnya ketika dalam berdagang atau melakukan usaha menggunakan sistem bagi hasil yang dimana kalau kamu tempurungnya

${ }^{16}$ Syamsuddin imam mesjid jami al-ittihad warga desa katumbangan, dusun katumbangan kecamatan campalagian kabupaten polewali mandar, 12 april 2020. 
ambil dan yang satunya lagi berupa uang tergantung kesepakatan di awal ijab dan kabul terus kalaupun misalnya orang yang mempekerjakan kan otomatis mau untung tidak apa-apa juga kalau sipekerjanya atau para pengelola mau bekerja sampai jam begini sesuai target maka saya kasih kamu gaji sekian yang jelas tidak terlalu memeras tenaga lalu upahnya tidak sesuai dan ketika terjadi kerugian dalam pengelolaan kelapa menjadi kopra putih sebenarnya kalau begitu menurut saya pribadi yah salah lah bagaimana tidak kerugiankan tidak ada yang tahu namanya juga berdagang berbisnis ada untung ruginya kalau misalnya rugi masa mau salahkan pekerjanya siapa tahu karena kurang beruntung lagi bukan musimnya untung laku seperti musim hujan begini kan hasinya kurang baik pengeringannya pun menjadi lama yang biasanya kelapa kopra dijemur 3 sampai 4 hari sudah kering ketika musim hujam menjadi 1 minggu baru kering dan siap di jual kita sebagai pemilik modal yang mempekerjakan harus sabar-sabar saja karena ada hikmah tersendiri yang bisa dipetik kalau dalam hukum islan tidak memandang seperti itu yang jelasnya adil saja lah jangan berat sebelah ${ }^{, 17}$

Penulis juga mewawancarai tokoh agama Ust. Muh. Amiruddin,S.S selaku guru pesantren hasan yamani dan MAN (Madrasah Alya Negeri) lampa. Penulis mempertanyakan mengenai tinjauan hukum islam terhadap sistem pembagian hasil pengelolaan kopra putih Di Desa Katumbangan, berikut wawancara penulis dengan Ust. Muh. Amiruddin,S.S yaitu:

"pemilik modal ketika mengalami kerugian maka gaji untuk karyawan sedikit dari biasanya, dan ketika normal maka sekian yang diterima karyawan. ketika perjanjian sudah seperti itu, tidak ada masalah karna sudah sama-sama rela tidak mensholimi. Kecuali dalam perjanjian rugi atau tidaknya dalam pengelolahan kelapa menjadi kopra, karyawan tetap digaji sesuai dengan akad atau perjanjian di awal. Jadi pemilik modal harus menanggung sepenuhnya kerugian yang kadang terjadi, namanya juga usaha ada untung dan ruginya. Intinya segala sesuatunya kembali ke akadnya, dalam usaha ketika pemilik modal bekerja sama dengan pengelolah dalam artian sama-sama ikhlas untung dan ruginya dibagi rata maka itu yang bagus, akan tetapi ketika dalam usaha tidak ada perjanjian di awal asal potong saja gaji karywan untuk menutupi kerugian maka itu yang tidak dibolehkan dalam islam "18

Dari wawancara di atas yang berhasil penulis rangkum dari ketiga tokoh agama Imam Mesjid Jami’ Al- Ittihad bapak Syamsuddin, ustazah ibu Nur Hidayah selaku guru ngaji dan ketua ibu-ibu pengajian di Desa Katumbangan dan Ust. Muh. Amiruddin,S.S selaku guru pesantren hasan yamani dan MAN (Madrasah Alya Negri) lampa, dapat disimpulkan bahwa pendapat bapak syamsuddin Imam Mesjid Jami Al- Ittihad dan mewakili pendapat dan keadaan masyarakat desa katumbangan sudah sesuai dengan yang telah di ajarkan dalam agama dan kepercayaan kita. Sebagaimana juga di jelaskan di dalam al-qur'an sebagai pedoman hidup manusia yang bisa di contoh dan diterapkan dalam kehidupan sehari- hari sebagai manusia,selama dalam kegiatan usaha pengelolaan kopra putih ini antara pengelola saling terbuka mengenai untung dan ruginya kegiatan usaha pengelolaan kopra putih ini maka akan selalu baik-baik saja intinya kembali ke ijab dan kabunya.

\footnotetext{
${ }^{17}$ Nur Hidayah ustazah guru ngaji dan ketua ibu-ibu pengajian di desa katumbangan dusun barasse kecamatan campalagian kabupaten polewali mandar,26 april 2020.

${ }^{18}$ Amiruddin,S.S guru pesantren Hasan Yamani dan MAN lampa kecamatan campalagian kabupaten polewali mandar,3 juni 2020.
} 
Menurut ustazah Nur Hidayah bahwa dalam kegiatan usaha harus adil seimbang dan sama rata sesuai kesepakatan di awal. bagaimana tidak, kerugiankan tidak ada yang tahu namanya juga berdagang berbisnis ada untung ruginya kalau misalnya rugi masa mau salahkan pekerjanya siapa tahu karena kurang beruntung, lagi bukan musimnya untung laku seperti musim hujan begini kan hasinya kurang baik pengeringannya pun menjadi lama yang biasanya kelapa kopra dijemur 3 sampai 4 hari sudah kering ketika musim hujam menjadi 1 minggu baru kering dan siap di jual kita sebagai pemilik modal yang mempekerjakan harus sabar-sabar saja karena ada hikmah tersendiri yang bisa dipetik kalau dalam hukum Islam tidak memandang seperti itu yang jelasnya adil saja lah jangan berat sebelah.

Sedangkan menurut ustadz Amiruddin, S.S segala sesuatunya itu kembali ke akadnya, jika dalam usaha antara pemilik modal dan pengelolah kopra putih menjaling kerja sama di antara keduanya sudah ada perjanjian mengenai sistem gaji dan untung rugi nya juga sudah disepakati di awal maka itu bagus dan tidak mensholimi, akan tetapi dalam kegiatan usaha tidak ada pemberitahuan sebelumnya langsung potong saja gaji pegawai ketika mengalami kerugian maka itu yang tidak boleh, mensholimi salah satu diantaranya.

Dari wawancara di atas antara penulis dan beberapa tokoh agama, maka penulis dapat menganalisis bahwa ketika dalam perhitungan pembagian gaji terjadi ketidak seimbangan di antara salah satu sistem pebagian gaji untuk karyawan maka besarannya yang di liat, ketika karyawan merasa disholimi dengan sistem pembagian gaji yang berlaku ketika kondisi atau terjadi masalah dalam kegiatan usaha yaitu mengalami kerugian maka antara pengelola dan karyawan harus saling mengkomunikasikan setiap masalah yang timbul dalam kegiatan usaha, saling terbuka dan saling bekerja sama agar kegiatan usaha yang dilakukan senantiasa berkah dan bernilai ibadah.

Tinjauan hukum Islam terhadap sistem bagi hasil pada usaha kopra putih di Desa Katumbangan yang menggunakan akad mudharabah. Yaitu akad atau perjanjian yang disepati antara pemilik modal dan pengelolah kopra putih di dalam hukum Islam segala sesuatunya itu Sah (boleh) diperbolehkan dalam Islam ketika sifatnya untuk kebaikan bersama tidak merugikan satu pihak atau mensholimi. Akan tetapi mana kala dari pihak pemilik modal mengambil hasil penjualan tempurung kelapa yang sudah menjadi hak dan upah bagi pengelola kopra putih untuk menutupi kerugian yang terjadi maka itu melukai satu pihak tidak sesuai dengan syariat Islam.

\section{PENUTUP}

Berdasarkan hasil penelitian tentang "Tinjauan ukum Islam mengenai sistem pembagian hasil pengelolaan kopra putih di Desa Katumbangan Kecamatan Campalagian Kabupaten Polewali Mandar" maka penulis dapat menyimpulkan bahwa:

A. Sistem pembagian hasil dalam pengelolaan kopra putih di Desa Katumbangan menggunakan 2 cara yaitu: diberi upah setelah mencapai 1000 biji di "sisi" senilai 160 ribu rupiah dan diberi tempurung kelapa setelah mengolah kelapa menjadi kopra putih, dari mulai memisahkan kelapa dengan tempurungnya, membela kelapa, menjemur, memisahkan buah kelapa dengan tempurungnya,memberi obat sebagai pengawet hingga menjadi kopra putih yang siap untuk di jual maka di beri upah tempurung kelapa, dalam bahasa mandar dan bahasa sehari-hari masyarakat Desa Katumbangan untuk berkomunikasi "kaddarona na ala"

B. Tinjauan hukum Islam terhadap sistem bagi hasil pada usaha kopra putih di Desa Katumbangan yang menggunakan akad mudharabah Yaitu akad atau perjanjian yang disepati 
antara pemilik modal dan pengelolah kopra putih di dalam hukum Islam segala sesuatunya itu Sah (boleh) diperbolehkan dalam Islam ketika sifatnya untuk kebaikan bersama tidak merugikan satu pihak atau mensholimi. Akan tetapi mana kala dari pihak pemilik modal mengambil hasil penjualan tempurung kelapa yang sudah menjadi hak dan upah bagi pengelola kopra putih untuk menutupi kerugian yang terjadi maka itu melukai satu pihak tidak sesuai dengan syariat Islam.

C. Kedua sistem diatas sudah disepakati oleh masyarakat Desa Katumbangan khususnya bagi pemodal dan pengelola kopra putih. Walaupun salah satu dari sistem pembagian upah di atas merugian sebagian karyawan para pekerja pengelolaan kopra putih akan tetapi pekerjaan ini tetap dilakukan untuk memenuhi kebutuhan hidup selain kegiatan membajak sawah hingga panen padi belum dilakukan maka pengelolaan kopra menjadi pekerjaan pengganti bagi para masyarakat khususnya bagi pengelola kopra putih.

\section{DAFTAR PUSTAKA}

Al-Qur'an dan terjemahannya Departemen Agama RI, , Bandung : CV penerbit J- ART,2005. Al-Qur'an dan Terjemahanya Departemen Agama RI, ,Bandung : CV Penerbit JART,h. 554. Al-Qur'an dan Terjemahanya Departemen Agama RI, , Bandung : CV Penerbit J-ART, 2005. Arrahman, Riski Ardian Pengaruh suhu dan lama pengeringan kopra terhadap rendemen minyak, skripsi Bandar lampung, Fkultas pertanian 2018

Antonio Syafi'I, Muhammad Bank Syariah : Dari Teori Ke Praktek, Jakarta: Gema Insani 2001

Al-Muslih Abdullah, Fikih Ekonomi Keuangan Islam, Jakarta : Darul Haq, 2004,

Az-Zuhaili Wahbah, Fiqih Islam Wa Adillatuhu Jilid 5, Jakarta : Gema Insani, 2011.

Az-Zuhaili, Wahbah Fiqh, Yogyakarta Penerbit :Pustaka pelajar...2011

Amiruddin,S.S guru pesantren Hasan Yamani dan MAN lampa kecamatan campalagian kabupaten polewali mandar,3 juni 2020.

Bisri Adib dan Munawwir, Al-Bisri Kamus Arab - Indonesia Indonesia-Arab, Surabaya : Pustaka Progressif, 1999,

Blogsome.com http://foragri, 15-11- 2011.Diakses pada kamis,2 Januari 2020. 10.36.wita

Dimyauddin,Djuwaini Pengantar Fiqh Muamalah, Yogyakarta: Pustaka Pelajar, 2008.

DSN Fatwa Indonesia No. 07/DSN-MUI/IV/2000 tentang Pembiayaan Mudharabahh Qiradh DSN Fatwa MUI Nomor 07/DSN-MUI/IV/2000,

Hendi Suhendi, Fiqh Muamalah, Jakarta: Rajawali Pers, 2011.

Hasan Ali Muh., Berbagai Macam Transaksi dalam Islam Fiqh Muamalat, Jakarta : PT RajaGrafindo Persada, 2003,

Https://id.m.wikipedia.org.Diakses pada 5 Januari 2020.01:30 wita

Imaniati Sri Neny dan Panji Adam Agus Putra.Hukum Bisnis penerbit: PT Refika Aditama Bandung cet 12017.

Isra, Sistem Keuangan Islam : Prinsip dan Operasi, Jakarta : Rajawali Pers, 2015.

Lumintang, Marsilia Indra Analisis daya saing kopra di Minahasa selatan,Jurnal,Manado,Fakultas Pertanian 2015

MuslichWardi Ahmad,editor, Lihhiati.-Ed.1,cet. 3.- Jakarta: Amzah, 2015. 

2010.

Mujieb Abdul, Mabruri Tholhah dan Syafi'ah, Kamus Istilah Fiqih, Jakarta: Pustaka Firdaus,

Profil Kantor Desa Katumbangan kecamatan campalagian, 18 Februari 2020

Phoenix. Pustaka Tim Kamus Besar Bahasa Indonesia Edisi Baru Jakarta:PT.Media Pustaka Phoenix.2009

Prof.Dr.shalah ash-shawi\& prof.Dr.Abdullah al-mushih.fighi ekonomi islam jakarta: Darul Haq, 2015

ISRA, Sistem Keuangan Islam :

Roham jamin, Abu Ensiklopedi Lintas Agama, Jakarta: Perpustakaan Nasional RI, 2009

Sayyid,Sabiq Fiqhus Sunnah Jilid 4, Jakarta : Darul Fath, 2004,

Sugiyono, Metode Penelitian Kombinasi Kualitatif dan Kuantitatif Bandung.Diakses pada 4 Januari 2020.10:10 Wita

Siloto Neprianus ,Perbandingan Pendapatan Petani Kopra Jamur dan Kopra Asap Studi Kasus Desa Paslaten Stu Kecamatan Tatapan Jurnal,Minahasa Selatan: Fakultas Sosial Ekonomi ,2017 mandar.

Syamsuddin pemilik kelapa warga dusun katumbangan,kec. Campalagian Kab Polewali

Syahrul Anisah Abu dan Fatwa bin Lukman, Mengenal Islam Lebih Dekat, Cet.1 Bogor: Media Tarbiyah,, 2014

www.pengertian pakar.com, Diakses pada tanggal 4 Januari 2020. 20.10 wita

Wawancara dengan ibu Lina, pemilik kelapa sekaligus pengola kelapa menjadi kopra Dusun Katumbangan, Campalagian

Wawancara dengan saudara aslan \& asrul, pemisah kelapa dengan sabuknya Dusun Katumbangan, Campalagian 15 maret 2020

Wawancara dengan bapak Sainuddin, pemilik kelapa sekaligus pengelola kelapa menjadi kopra putih warga dusun katumbangan, campalagian, mandar

Wawancara dengan bapak Syamsuddin, pemilik kelapa Dusun Katumbangan, Campalagian

Wawancara dengan ibu Nur baya, pengelolakopra putih Dusun Katumbangan, Campalagian 3 Maret 2020 